\title{
Walnut and Hazelnut Shells: Untapped Industrial Resources and Their Suitability in Lignocellulosic Composites
}

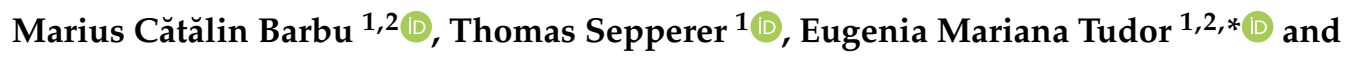 \\ Alexander Petutschnigg ${ }^{1}$ \\ 1 Forest Products Technology and Timber Construction Department, Salzburg University of Applied Sciences, \\ Markt 136a, 5431 Kuchl, Austria; cmbarbu@unitbv.ro (M.C.B.); thomas.sepperer@fh-salzburg.ac.at (T.S); \\ alexander.petutschnigg@fh-salzburg.ac.at (A.P.) \\ 2 Faculty of Wood Engineering, University of Transilvania in Brasov, Romania, Bld. Eroilor nr.29, \\ 500036 Brasov, Romania \\ * Correspondence: eugenia.tudor@fh-salzburg.ac.at
}

Received: 24 August 2020; Accepted: 10 September 2020; Published: 11 September 2020

\begin{abstract}
Walnut and hazelnut shells are agricultural by-products, available in high quantities during the harvest season. The potential of using these two agricultural residues as raw materials in particleboard production has been evaluated in this study. Different panels with either walnut or hazelnut shells in combination with melamine-urea formaldehyde or polyurethane at the same level of $1000 \mathrm{~kg} / \mathrm{m}^{3}$ density were produced in a laboratory hot press and mechanical properties (modulus of elasticity, bending strength, and Brinell hardness) and physical properties (thickness swelling and water absorption) were determined, together with formaldehyde content. Although Brinell hardness was $35 \%$ to $65 \%$ higher for the nutshell-based panels, bending strength and modulus of elasticity were $40 \%$ to $50 \%$ lower for the melamine-urea formaldehyde bonded nutshells compared to spruce particleboards, but was $65 \%$ higher in the case of using polyurethane. Water absorption and thickness swelling could be reduced significantly for the nutshell-based boards compared to the spruce boards (the values recorded ranged between $58 \%$ to $87 \%$ lower as for the particleboards). Using polyurethane as an adhesive has benefits for water uptake and thickness swelling and also for bending strength and modulus of elasticity. The free formaldehyde content of the lignocellulosic-based panels was included in the E0 category $(\leq 2.5 \mathrm{mg} / 100 \mathrm{~g})$ for both walnut and hazelnut shell raw materials and the use of polyurethane improved these values to super E0 category ( $\leq 1.5 \mathrm{mg} / 100 \mathrm{~g})$.
\end{abstract}

Keywords: hazelnut; walnut; shells; lignocellulosic composites; UF; PUR; formaldehyde content

\section{Introduction}

The continuous interest in the efficient use and reuse of resources in the wood and agricultural sector for upcycled applications [1] is of great interest nowadays [2,3] in the context of the circular economy [4].

Steered by the paucity of non-renewable resources, the interest for wood could exceed its sustainable supply within the next few decades [5]. The wood demand has increased steadily, not only in the industry or for energy production (more than $50 \%$ ), while the supply of wood is limited in specific regions of the world [6]. This leads to the need for substitutes for wood in engineered wood products (e.g., particleboards, PB). A promising alternative for wood in composites is provided by agricultural residues. A lot of research on agricultural waste has been carried out for PB based on wheat straw [7,8], rice straw [9,10], rapeseed [11], hemp shives [12,13], cotton dust [14], or sunflower stalks [15] and topinambour [16]. Brewer's spent grain is also a raw material for PB [17] together 
with tree bark [18-20]. The advantages of these agricultural and forestry by-products include reduced costs, ample availability, biodegradability, and renewability, followed by an enlarged flexibility and sound insulation [21,22]. Some drawbacks in using agricultural residues in lignocellulosic composites include unequal availability over the year, the manufacture of products with these raw materials cannot run year-round, no industrialized processing yet, big storage facilities, and different necessary pre-treatments [23-25]. Walnut and hazelnut shells are agricultural residues available in high quantities, but despite their thermal utilization [26], with no industrial use yet. Nut shells can exhibit high hardness and toughness [27]. Worldwide walnut production in 2019/2020 was roughly 965,400 tons and 528,070 tons for hazelnut [28]. Taking in account that roughly $67 \%$ of the total fruit weight is comprised of the shell leads to 646,818 tons of walnut shells and roughly 353,807 tons of hazelnut shells each year [29]. Especially in Iran and Turkey research on the solely use of nutshells and nutshells in combination with wood has been done. The authors in [30] studied the properties of particleboard from hazelnut husks and combined with European black pine (Pinus nigra Arnold) [31,32]. Walnut shells were studied by $[33,34]$. Other research refers to particleboards manufactured with peanut hulls mixed with European black pine [35], peanut shell flour [36], and almond shells [37-39].

The aim of this study was to compare and evaluate the influence of the nutshell type (hazelnut and walnut) and resin (bonded with melamine urea formaldehyde (MUF) and polyurethane (PUR) $10 \%$ each) on the mechanical and physical properties and on the free formaldehyde content of particleboards produced solely from the above-mentioned nutshells. Other studies have dealt with PB bonded only with UF, so this study brings a novel process of gluing the nut shell panels with MUF and PUR as the properties of these boards including the Brinell hardness and formaldehyde content have not been reported yet.

\section{Materials and Methods}

The raw materials used for the particleboard production consisted of walnut and hazelnut shells. The hazelnut (Corylus avellana L.) shells were provided by the Faculty of Forestry at the University of Zagreb (Croatia). The walnut (Juglans regia L.) shells were provided by a family-owned walnut cracking company in Carinthia (Maria Rojach, Austria). Melamine urea formaldehyde (MUF) resin (Prefere 10G268) was provided by metaDynea (Krems, Austria) and polyurethane (PUR 501.0) was provided by Kleiberit Klebchemie (Kleiberit Klebchemie M. G. Becker GmbH \& Co. KG, Weingarten, Germany).

A total of $40 \mathrm{~kg}$ walnut shells and $30 \mathrm{~kg}$ hazelnut shells were available for the project. The shells were at first manually cleaned from impurities and afterward shredded in an R40 industrial four shaft shredder at Untha Company (Kuchl, Austria) using an 8-mm screen. The shredded nutshells were dried in a Brunner-Hildebrand High VAC-S, HV-S1 (Hannover, Germany) kiln dryer for three days to reach a moisture content of about $5 \%$. After drying, the particles were sorted into three main size classes (fine-grained, middle-grained and coarse-grained) using a sieve shaker Retsch AS 200 (Haan, Deutschland). Particles in the middle-sized $(3-6 \mathrm{~mm})$ and fine $(<3 \mathrm{~mm})$ fraction were used for the board production. The percentage of particles in each group and nutshell type is listed in Table 1.

Table 1. Weight distribution according to the fraction size of the raw material.

\begin{tabular}{cccc}
\hline Raw Material & \% Fine-Grained & \% Middle-Sized Grained & \% Coarse-Grained \\
\hline Hazelnut & 13.4 & 67.1 & 19.5 \\
Walnut & 12.4 & 73.4 & 14.2 \\
\hline
\end{tabular}

A total of twelve boards (two for each group) was produced, of which the compositions are listed in Table 2. 
Table 2. Manufacturing parameters of particleboards made from hazelnut, walnut, and spruce.

\begin{tabular}{cccccc}
\hline Board & Adhesive & Raw Material & Density $\left.\mathbf{( k g} / \mathbf{m}^{\mathbf{3}}\right)$ & Press Time $(\mathbf{m i n})$ & Press Temp. $\left({ }^{\circ} \mathbf{C}\right)$ \\
\hline A & MUF & Hazelnut & 1000 & 6 & 160 \\
B & MUF & Walnut & 1000 & 6 & 160 \\
C & MUF & Spruce & 1000 & 6 & 160 \\
D & PUR & Hazelnut & 1000 & 20 & 60 \\
E & PUR & Walnut & 1000 & 20 & 60 \\
F & UF & Spruce & 700 & 6 & 180 \\
\hline
\end{tabular}

The $320 \mathrm{~mm} \times 320 \mathrm{~mm}$ boards were produced with a thickness of $10 \mathrm{~mm}$ and a density of $1000 \mathrm{~kg} / \mathrm{m}^{3}$ for nutshells and $700 \mathrm{~kg} / \mathrm{m}^{3}$ for the spruce control boards. The density of $1000 \mathrm{~kg} / \mathrm{m}^{3}$ could not be reached with wood particles due to the technical limitations of the hydraulic press Höfer HLOP 280. The walnut and hazelnut boards were composed of $70 \%$ middle-sized and $30 \%$ coarse-grained particles.

For all panels, the particles were mixed with resin manually and then formed into a mat and pre-compressed. This mat was pressed afterward in a hydraulic laboratory press (Höfer HLOP 280, Taiskirchen, Austria) with a pressure of $3 \mathrm{~N} / \mathrm{mm}^{2}$. For the UF and MUF bonded boards, $10 \%$ resin based on weight was used including $1 \%$ ammonium sulfate as a hardener. These boards (Figure 1) were pressed at $160{ }^{\circ} \mathrm{C}$ for $6 \mathrm{~min}$. The PUR bonded boards were also produced with $10 \%$ adhesive, but these were pressed at $60^{\circ} \mathrm{C}$ for $20 \mathrm{~min}$. After pressing, the panels were conditioned at $20^{\circ} \mathrm{C}$ and $65 \%$ relative air humidity for one week before cut to test specimen size, which was done according to [40].

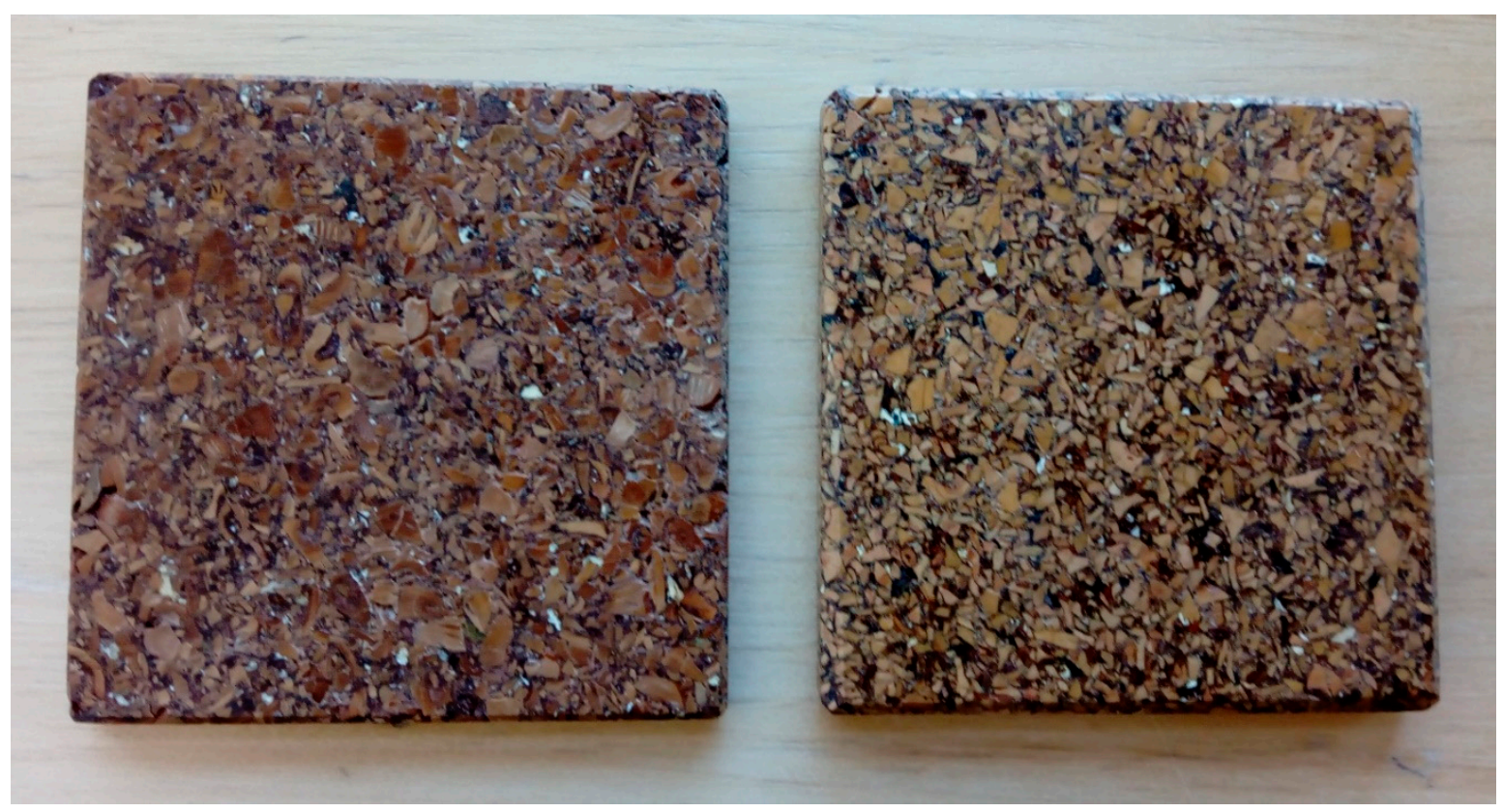

Figure 1. Hazelnut and walnut $10 \mathrm{~mm}$ thick samples bonded with PUR; $1000 \mathrm{~kg} / \mathrm{m}^{3}$ density; composition: $70 \%$ fine-grained particles ( $<3 \mathrm{~mm}$ ) and 30\% coarse-grained particles $(3-6 \mathrm{~mm})$.

In terms of mechanical properties, bending strength (MOR) and modulus of elasticity (MOE) according to [41] and Brinell Hardness [42] were tested.

For the bending properties [41], the three-point bending test was employed.

The physical properties such as thickness swelling and water absorption after $24 \mathrm{~h}$ water immersion [43] and density [44] were also measured. 
To determine the formaldehyde content of the panels, $250 \mathrm{~mm} \times 250 \mathrm{~mm}$ boards with fine-grained particles $(<3 \mathrm{~mm})$ and $10 \mathrm{~mm}$ thickness and a density of $1000 \mathrm{~kg} / \mathrm{m}^{3}$ were manufactured with walnut and hazelnut shells. Moisture content (m.c.) was measured for each type of board (Table 3).

Table 3. Moisture content of the nutshell boards prior to determining the formaldehyde content with the perforator method.

\begin{tabular}{cccc}
\hline Board & Glue & m.c. (\%) & Particle Size (mm) \\
\hline Walnut & UF & 1.79 & $<3 \mathrm{~mm}$ \\
Walnut & PUR & 5.25 & $<3 \mathrm{~mm}$ \\
Hazelnut & UF & 2.28 & $<3 \mathrm{~mm}$ \\
Hazelnut & PUR & 6.28 & $<3 \mathrm{~mm}$ \\
\hline
\end{tabular}

Each board was cut into $2.5 \times 2.5 \mathrm{~mm}$ samples after cooling. The test specimens were placed in airtight bags and delivered to the Kaindl Company, Wals, Salzburg, Austria, where formaldehyde content was measured according to [45]. This method is recommended for nonlaminated and uncoated wood-based panels.

\section{Results}

For all boards described earlier, the mechanical and physical properties were evaluated according to the corresponding standard and statistically analyzed using mean separation tests and ANOVA.

\subsection{Mechanical Properties}

In terms of mechanical properties, MOE, MOR and Brinell hardness have been evaluated. The mean value, standard deviation, and minimal and maximal values are listed in Table 4. Results of ANOVA are indicated by letters a-e and $\mathrm{u}-\mathrm{z}$. The first letter refers to the different raw material (for values with the same letter, the raw material has no significant influence), the second letter refers to the used adhesive (again, and for values with the same letter, the adhesive has no influence).

Table 4. Mechanical properties of the hazelnut, walnut, and spruce particle boards.

\begin{tabular}{|c|c|c|c|c|c|}
\hline Properties & Board & Mean & Std. Dev. & Min & $\operatorname{Max}$ \\
\hline \multirow[t]{6}{*}{ MOE [GPa] } & A & $1.13^{a, u}$ & 0.42 & 0.73 & 1.79 \\
\hline & $\mathrm{B}$ & $1.15^{b, v}$ & 0.29 & 1.20 & 1.96 \\
\hline & $\mathrm{C}$ & $2.57^{c, w}$ & 0.36 & 2.12 & 3.00 \\
\hline & $\mathrm{D}$ & $1.32^{\mathrm{d}, \mathrm{u}}$ & 0.30 & 0.92 & 1.60 \\
\hline & $\mathrm{E}$ & $1.30^{\mathrm{d}, \mathrm{x}}$ & 0.44 & 0.68 & 1.70 \\
\hline & F & $0.86^{\mathrm{e}, \mathrm{y}}$ & 0.13 & 0.65 & 1.00 \\
\hline \multirow[t]{6}{*}{$\operatorname{MOR}\left[\mathrm{N} / \mathrm{mm}^{2}\right]$} & A & $4.25^{\mathrm{a}, \mathrm{u}}$ & 1.21 & 2.55 & 5.47 \\
\hline & B & $5.20^{\mathrm{a}, \mathrm{w}}$ & 1.02 & 3.79 & 6.53 \\
\hline & $\mathrm{C}$ & $13.26^{b, y}$ & 2.04 & 11.09 & 16.26 \\
\hline & $\mathrm{D}$ & $7.43^{c, v}$ & 1.34 & 5.36 & 8.65 \\
\hline & $\mathrm{E}$ & $8.86^{c, x}$ & 2.75 & 5.35 & 12.18 \\
\hline & $\mathrm{F}$ & $5.47^{\mathrm{d}, \mathrm{z}}$ & 0.75 & 4.33 & 6.32 \\
\hline \multirow[t]{6}{*}{ Brinell hardness $\left[\mathrm{N} / \mathrm{mm}^{2}\right]$} & A & $62.50^{a, u}$ & 12.55 & 39.95 & 82.65 \\
\hline & B & $43.70^{b, v}$ & 7.07 & 36.57 & 57.72 \\
\hline & $\mathrm{C}$ & $28.00^{c, x}$ & 5.48 & 22.26 & 35.39 \\
\hline & $\mathrm{D}$ & $53.90^{\mathrm{d}, \mathrm{u}}$ & 12.70 & 27.82 & 70.59 \\
\hline & $\mathrm{E}$ & $55.50^{d, w}$ & 8.51 & 37.30 & 63.89 \\
\hline & F & $18.00^{e, y}$ & 3.08 & 15.26 & 22.82 \\
\hline
\end{tabular}

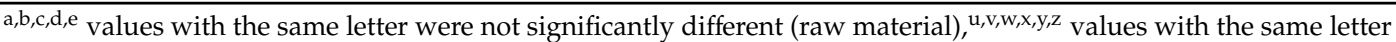
were not significantly different (adhesive). 


\subsubsection{MOE and MOR}

For the MUF bonded boards, the walnut shell ones (B) performed better in terms of MOE (1.51 GPa) and a MOR of $5.20 \mathrm{~N} / \mathrm{mm}^{2}$ compared to boards made from hazelnut shells (A) with an MOE of 1.30 GPa and a MOR of $4.25 \mathrm{~N} / \mathrm{mm}^{2}$ (Table 4). Although ANOVA showed that the material had a statistically significant influence in terms of MOE, it did not have an influence on the MOR. When PUR was used as an adhesive, it did not make a difference whether the boards were made of hazelnut (D) or walnut (E) shells. MOE was roughly 1.3 GPa for both, MOR 7.43 and $8.86 \mathrm{~N} / \mathrm{mm}^{2}$ for hazelnut and walnut shell boards, respectively. Furthermore, ANOVA showed that for walnut shell boards, it did not make a difference if MUF or PUR (both at a concentration of 10 w.t. \%) was used as an adhesive when it came to MOE, while it did influence the MOR. When hazelnut shells were used as a raw material, the adhesive had a statistically significant influence on both MOE and MOR. The reference boards made from spruce and MUF (C) achieved the highest values for MOE and MOR (2.57 GPa and $13.26 \mathrm{~N} / \mathrm{mm}^{2}$, respectively). Surprisingly, the PUR bonded spruce boards (F) performed weaker than the nutshell panels (0.87 GPa for MOE and $5.47 \mathrm{~N} / \mathrm{mm}^{2}$ for MOR). The results for both hazelnut and walnut panels bonded with PUR were similar to the values obtained by [34], namely a MOR between 6 and $9 \mathrm{~N} / \mathrm{mm}^{2}$ and an MOE between 0.8 and $1.3 \mathrm{GPa}$. When the same amount of hazelnut shells was mixed with wood particles $(50 \%+50 \%)$, the values of the MOE and MOR increased significantly [32].

In terms of MOE (Table 4), the walnut shell boards showed higher values than the ones produced by [46], which reached $1.15 \mathrm{GPa}$ on average compared to $1.51 \mathrm{GPa}$ and might have been caused by the adhesive used. The study by [46] applied UF, while for these boards was utilized a less brittle MUF [47]. Another reason might be that [46] produced boards with a density of $700 \mathrm{~kg} / \mathrm{m}^{3}$ while those boards had a target density of $1000 \mathrm{~kg} / \mathrm{m}^{3}$ [48].

The results for MOE and MOR of the nutshell boards were expected to range below the results of spruce particleboards. This can be traced back to the fact that the mechanical properties are strongly influenced by different properties of the raw material like density, chemical composition, and particle size. A low-density raw material allows a higher compression in the panel, leading to improved performance in bending tests [49]. Given that the density of the used nutshells was very high (between 700 and $1030 \mathrm{~kg} / \mathrm{m}^{3}$ depending on the fraction) and spruce particles have a density of $450 \mathrm{~kg} / \mathrm{m}^{3}$, the lower performance of the MUF bonded nutshell boards can be traced back to a lower compression rate [50]. The weak behavior of the PUR bonded spruce boards can be traced back to unsatisfying bonding, caused by an insufficient moisture content of the raw material (3\%) for the adhesive to react [51].

\subsubsection{Brinell Hardness}

Boards made from hazelnut shells and MUF (A) showed the highest average Brinell hardness with $62.5 \mathrm{~N} / \mathrm{mm}^{2}$ while the lowest hardness value was achieved by PUR bonded spruce particles with only $18 \mathrm{~N} / \mathrm{mm}^{2}$ (Table 4). The highest value was achieved by hazelnut with $82.6 \mathrm{~N} / \mathrm{mm}^{2}$ while the lowest for those panels was $39.9 \mathrm{~N} / \mathrm{mm}^{2}$. The big difference between the highest and lowest value and the high standard deviation can be explained as a result of the different measuring spots and the manual scattering of raw material in the press mold. This showed that the hardness was very high when measured on a big piece of the nutshells, while it was much lower when determined on the fine-grained particles that are filling the gaps between the coarse ones. This was not only valid for MUF, but also for PUR. The highest Brinell hardness value for a hazelnut board glued with PUR (D) was $70.59 \mathrm{~N} / \mathrm{mm}^{2}$ while the lowest was $27.82 \mathrm{~N} / \mathrm{mm}^{2}$. The mean was determined at $54 \mathrm{~N} / \mathrm{mm}^{2}$. Walnut panels showed similar results this time, PUR bonded boards (E) performed a little better with an average Brinell hardness of $55.5 \mathrm{~N} / \mathrm{mm}^{2}$, while MUF boards (B) only reached $43.7 \mathrm{~N} / \mathrm{mm}^{2}$. The highest value for the walnut boards was $63.9 \mathrm{~N} / \mathrm{mm}^{2}$ for those produced with PUR. ANOVA showed that when it came to PUR bonded boards, the nutshell type had no influence. There was also no statistically significant difference for hazelnut boards concerning the adhesive. Compared to spruce particleboards that showed an average result of $18 \mathrm{~N} / \mathrm{mm}^{2}$ for PUR and $28 \mathrm{~N} / \mathrm{mm}^{2}$ for MUF, the nutshells were much 
harder. However, the results for the wood-based boards were closely distributed to the mean value, with a standard deviation of only $3 \mathrm{~N} / \mathrm{mm}^{2}$. This means that the spot where the force is applied is less relevant compared to the nutshell boards.

\subsection{Physical Properties}

In terms of physical properties, thickness swelling (TS) and water absorption (WA) both after $24 \mathrm{~h}$ water immersion were evaluated.

Thickness swelling after $24 \mathrm{~h}$ water immersion for MUF bonded hazelnut husk panels (A) was determined with $17.5 \%$ while it was a little lower for walnut shells (B) with $13.2 \%$ (Table 5). Compared to the spruce reference board (C) with an average of $52 \%$, the increase in thickness was much lower. The results for hazelnut (A) glued with MUF were a little better compared to those obtained by [31] and [35] (29.3\% TS with a standard deviation of 3.5\%), while the results for walnut (B) were higher compared to [34], who evaluated the thickness swelling with $10.2 \%$.

Table 5. Physical properties of the hazelnut, walnut, and spruce particle boards.

\begin{tabular}{cccccc}
\hline Properties & Board & Mean & Std. dev. & Min & Max \\
\hline TS 24 h [\%] & A & $17.47^{\mathrm{a}, \mathrm{u}}$ & 2.88 & 13.56 & 21.91 \\
& $\mathrm{~B}$ & $13.23^{\mathrm{b}, \mathrm{w}}$ & 1.35 & 10.98 & 15.21 \\
& C & $52.09^{\mathrm{c}, \mathrm{y}}$ & 7.84 & 42.69 & 64.84 \\
& $\mathrm{D}$ & $9.66^{\mathrm{d}, \mathrm{v}}$ & 1.48 & 8.33 & 12.66 \\
& E & $8.37^{\mathrm{d}, \mathrm{x}}$ & 1.26 & 6.48 & 10.29 \\
& F & $44.48^{\mathrm{e}, \mathrm{z}}$ & 11.01 & 30.92 & 64.39 \\
\hline WA 24 h [\%] & A & $26.96^{\mathrm{a}, \mathrm{u}}$ & 2.96 & 23.32 & 32.54 \\
& $\mathrm{~B}$ & $24.54^{\mathrm{a}, \mathrm{w}}$ & 3.55 & 19.29 & 28.78 \\
& $\mathrm{C}$ & $64.00^{\mathrm{b}, \mathrm{y}}$ & 9.64 & 45.24 & 75.02 \\
& $\mathrm{D}$ & $12.44^{\mathrm{c}, \mathrm{v}}$ & 2.05 & 9.60 & 15.28 \\
& $\mathrm{E}$ & $11.49^{\mathrm{c}, \mathrm{x}}$ & 2.56 & 7.40 & 14.40 \\
& F & $89.99^{\mathrm{d}, \mathrm{z}}$ & 7.04 & 81.49 & 104.09 \\
\hline
\end{tabular}

$\mathrm{a}, \mathrm{b}, \overline{\mathrm{c}, \mathrm{d}, \mathrm{e}}$ values with the same letter were not significantly different (raw material), ${ }^{\mathrm{u}, \mathrm{V}, \mathrm{w}, \mathrm{x}, \mathrm{y}, \mathrm{z}}$ values with the same letter were not significantly different (adhesive).

Thickness swelling after $24 \mathrm{~h}$ was significantly reduced when PUR was used to produce the boards. This means that it was only $9.7 \%$ for hazelnut (D) and $8.4 \%$ for walnut (E). The spruce boards showed an increase in thickness of nearly $52 \%$ for MUF and still $44.5 \%$ for PUR. The nutshells in combination with PUR performed better compared to the spruce particles. It was found that when MUF was used as the adhesive, there was a significant difference between the walnut and hazelnut shells, while the material did not have a big influence when bonded with PUR.

The results for water absorption after $24 \mathrm{~h}$ water submersion were similar to those for thickness swelling after $24 \mathrm{~h}$ (Table 5). This means that the nutshell boards glued with MUF had a higher water uptake, namely $27 \%$ for hazelnut (A) and $25 \%$ for walnut (B), compared to the PUR bonded ones with $12.5 \%$ (D) and $11.5 \%$ (E), respectively. The values were much lower compared to the results of spruce particles with $64 \%$ for MUF (C) and almost $90 \%$ for PUR (F). Regarding water uptake over $24 \mathrm{~h}$, there was no influence of the used nutshell type in combination with either MUF or PUR.

The same trend of blocking and reduction of TS and WA was observed in the case of using hazelnut shells combined with wood particles [32], with a mean of $20 \%$ for TS and $70 \%$ for WA and from [34], in the case of walnut shells with the same value for TS as reported by [32] and lower WA of $37 \%$.

It was expected that thickness swelling and water absorption will be lower, compared to the spruce particleboards. The water uptake of lingo-cellulosic materials is strongly influenced by the number of free hydroxyl groups where water is bonded to. These hydroxyl groups are mainly present in the natural polymer cellulose. Hemicellulose is amorphous and has a hydrophilic character that is 
additionally increasing the water uptake. Lignin, however, is totally hydrophobic, which means that water cannot be absorbed within [52]. The high amount of lignin in the walnut shells (49.1\%) compared to roughly $35 \%$ in softwood indicated a decreased amount of water absorption. Furthermore, hazelnut husks contain almost $42 \%$ of lignin and only $55 \%$ of holocellulose compared to $65 \%$ in softwood.

PUR is more hydrolytically stable than MUF, which explains the big differences for thickness swelling and water absorption when these two adhesives are compared. The high value for water absorption for the PUR glued spruce particleboards was again caused by the low (3\%) moisture content of the raw material and a non-complete reaction of the adhesive.

\subsection{Formaldehyde Content}

The corrected values of free formaldehyde content varied depending on the type of adhesive formulation for the board (Figures 2 and 3).

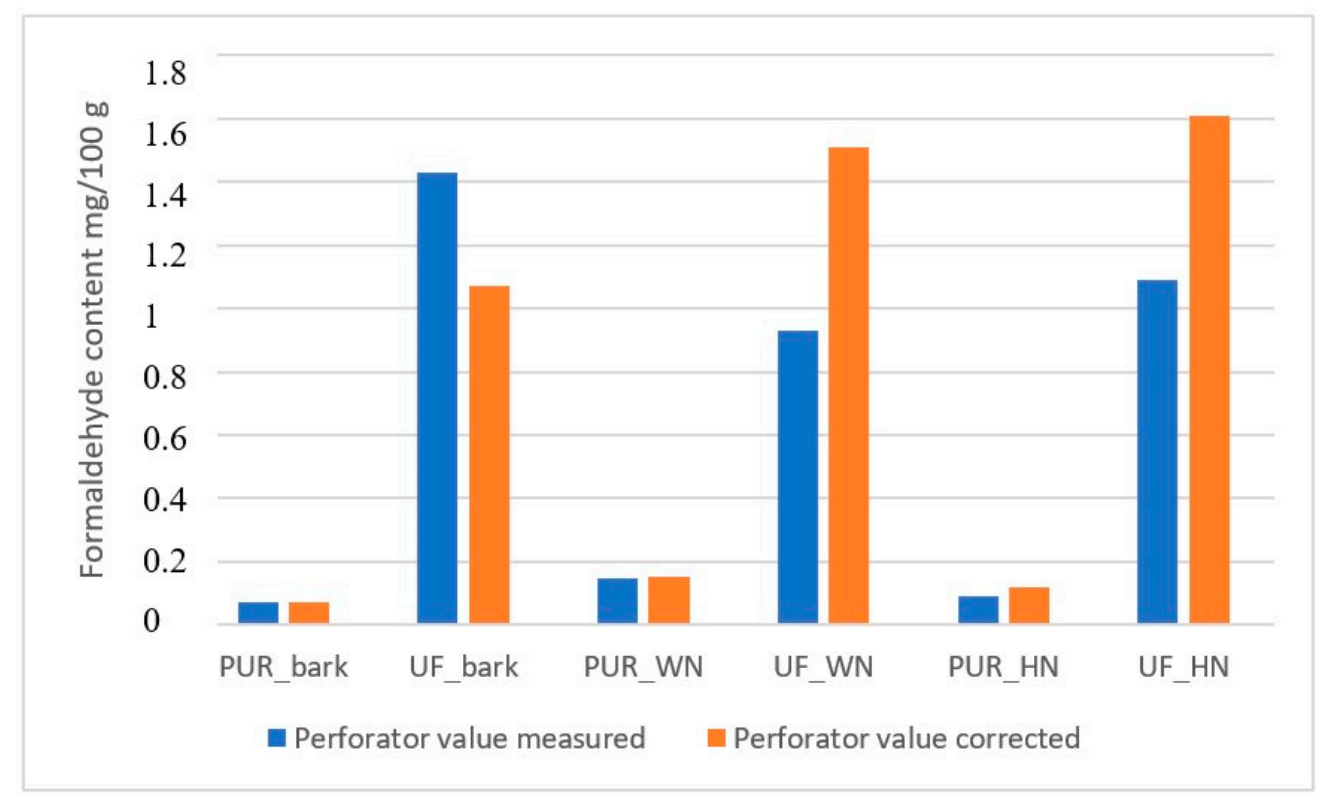

Figure 2. Free formaldehyde content for both the measured and corrected perforator values (EN 120:2011) of samples of walnut and hazelnut shell boards compared with larch bark panels from [53].

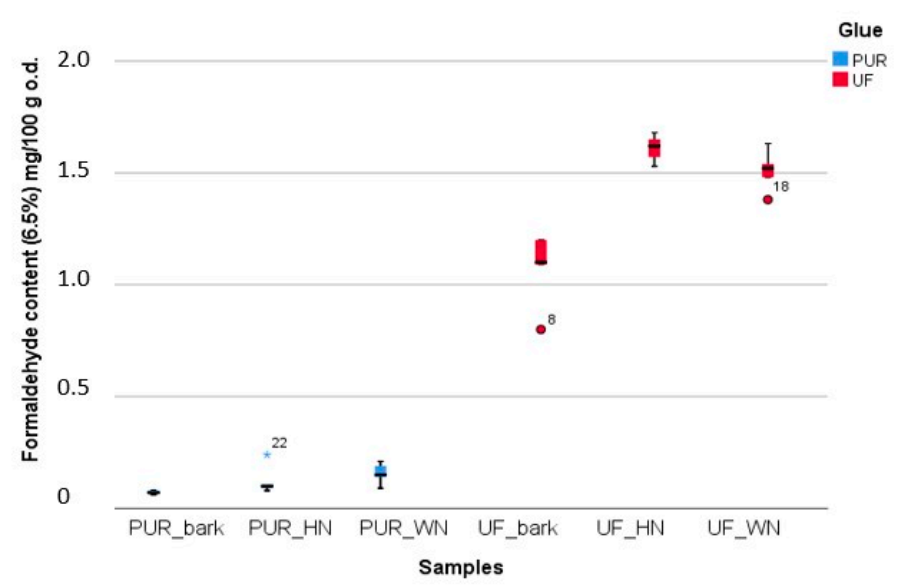

Figure 3. Free formaldehyde content measured according to EN 120:2011 of $10 \mathrm{~mm}$ walnut and hazelnut panels bonded with UF and MUF and compared with the values of larch bark boards glued with the same adhesives from [53]. 
The values for walnut and hazelnut shell panels were compared with similar $10 \mathrm{~mm}$ boards manufactured with the same adhesives reported by [53]. The lowest formaldehyde content of 0.07 $\mathrm{mg} / 100 \mathrm{~g}$ oven dry was measured for the board with larch bark bonded with PUR (PUR_bark). This is included in the super E0 classification $(\leq 1.5 \mathrm{mg} / 100 \mathrm{~g})$. In the same category were comprised the values of the walnut (PUR_WN) and hazelnut (PUR_HN) shell boards glued with PUR and the larch bark board bonded with UF. To the E0 class $(\leq 2.5 \mathrm{mg} / 100 \mathrm{~g})$ belonged the values for the nutshell boards bonded with UF (UF_HN and UF_WN). These results are consistent with those obtained by [54] regarding formaldehyde release from low-emission wood-based panels using the perforator method, which ranged from 0.71 to $2.99 \mathrm{mg} / 100 \mathrm{~g}$ and was slightly lower than that of [34].

The role of bark to decrease the formaldehyde content of wood-based composites was also studied by $[55,56]$. It was expected that the level of free formaldehyde content of the panels glued with PUR would be significantly lower than that of the boards bonded with UF, but the combination of both adhesives and raw materials resulted in panels that reached at least the E0 classification.

\section{Conclusions}

This study has shown that the nutshells can be used for the manufacture of PBs with improved performances in terms of physical properties (dimensional stability), but also with higher Brinell hardness compared to the spruce particleboards.

MOR and MOE are lower by roughly 50\% and cannot meet the requirements for P1 or P2 PBs, according to EN 310:2005. Future research should consider the improvement potentials by choosing the proper percentage of nutshells chips, combining the coarse-grained particles with the fine-grained ones, in order to fill voids in-between, combined with a proper bonding system.

This study has also shown that, when MUF is used to bond the boards, the raw material has no influence on MOR and water absorption, when PUR is used, the raw material has no influence on MOE, but with an improvement in terms of MOR (35\% higher compared to spruce particles), Brinell hardness (up to $67 \%$ ), thickness swelling (65-75\% lower), and water absorption (58-87\% lower). There is no statistically significant influence of the adhesive for hazelnut shells in terms of MOE and Brinell hardness.

The values of the formaldehyde content are all included in the E0 emission class. In the case of the panels bonded with PUR, the measured values were less than $1.5 \mathrm{mg} / 100 \mathrm{~g}$, which means that the super E0 category was reached. All these perforator results for the panels manufactured with hazelnut and walnut shells recommend them as low-emissions lignocellulosic composites.

The nutshells, utilized only for energy purposes [57], could be considered as a raw material in particleboard production. Further research can focus on the properties of improved formulations for adhesives and lignocellulosic particles, eventually with reinforcements [58] to achieve similar properties to P1 and P2 [59].

Author Contributions: Conceptualization, T.S.; Methodology, T.S. and E.M.T. Validation, E.M.T.; Formal analysis, A.P. and M.C.B.; Investigation, T.S.; Resources, T.S.; Writing-original draft preparation, T.S. and E.M.T.; Writing - review and editing, T.S. and E.M.T.; Visualization, T.S., and M.C.B.; Supervision, A.P. and M.C.B. All authors have read and agreed to the published version of the manuscript.

Funding: This research received no external funding.

Acknowledgments: The authors would like to thank Frederick Kamke from Oregon State University (Oregon, USA) for making the project possible and his support throughout the project; Danijela Domljan from the University of Zagreb (Croatia) for providing the hazelnut shells used for the board production in this project and to Kaindl Co. in Salzburg for supporting this research with the determination of the formaldehyde content of the walnut and hazelnut samples.

Conflicts of Interest: The authors declare no conflict of interest. 


\section{References}

1. Tudor, E.M.; Zwicl, C.; Eichinger, C.; Petutschnigg, A.; Barbu, M.C. Performance of softwood bark comminution technologies for determination of targeted particle size in further upcycling applications. J. Clean. Prod. 2018, 269, 122412. [CrossRef]

2. Queirós, C.; Cardoso, S.; Lourenço, A.; Ferreira, J.M.I.; Lourenço, M.; Pereira, H. Characterization of walnut, almond, and pine nut shells regarding chemical composition and extract composition. Biomass Convers. Biorefinery 2019, 10. [CrossRef]

3. de Carvalho Araújo, C.; Salvador, R.; Piekarski, C.; Sokulski, C.; de Francisco, A.; Camargo, S. Circular Economy Practices on Wood Panels: A Bibliographic Analysis. Sustainability 2019, 11, 1057. [CrossRef]

4. Fan, Y.; Lee, C.; Lim, J.; Klemeš, J. Cross-disciplinary approaches towards smart, resilient and sustainable circular economy. J. Clean. Prod. 2019, 232, 1482-1491. [CrossRef]

5. Risse, M.; Weber-Blaschke, G.; Richter, K. Resource efficiency of multifunctional wood cascade chains using LCA and exergy analysis, exemplified by a case study for Germany. Resour. Conserv. Recycl. 2017, 126, 141-152. [CrossRef]

6. Eurostat. Wood Products-Production and Trade. Available online: https://ec.europa.eu/eurostat/statisticsexplained/index.php/Wood_products_-_production_and_trade (accessed on 19 August 2020).

7. Boquillon, N.; Elbez, G.; Schönfeld, U. Properties of wheat straw particleboards bonded with different types of resin. J. Wood Sci. 2004, 50, 230-235. [CrossRef]

8. Wang, D.; Sun, S. Low density particleboard from wheat straw and corn pith. Ind. Crop. Prod. 2002, 50, 43-50. [CrossRef]

9. Luo, P.; Yang, C.; Li, M.; Wang, Y. Manufacture of thin rice straw particleboards bonded with various polymeric methane diphenyl diisocyanate/ urea formaldehyde resin mixtures. BioResources 2020, 15, 935-944.

10. Yasina, M.; Waheed Bhutto, A.; Bazmi, A.; Karim, S. Efficient Utilization of Rice-wheat Straw to Produce Value-added Composite Products. J. Environ. Chem. Eng. 2010, 1, 1-8.

11. Dukarska, D.; Czarnecki, R.; Dziurka, D.; Mirski, R. Construction particleboards made from rapeseed straw glued with hybrid pMDI/PF resin. Eur. J. Wood Prod. 2017, 75, 175-184. [CrossRef]

12. Balducci, F.; Harper, C.; Meinlschmidt, P.; Dix, B.; Sanasi, A. Development of Innovative Particleboard Panels. Drv. Ind. 2008, 59, 131-136.

13. Réh, R.; Vrtielka, J. Modification of the core layer of particleboard with hemp shives and its influence on the particleboard properties. Acta Fac. Xylologiae 2013, 55, 51-59.

14. Nemli, G.; Odabas Serin, Z.; Özdemir, F.; Ayrılmış, N. Potential use of textile dust in the middle layer of three-layered particleboards as an eco-friendly solution. BioResources 2019, 14, 120-127.

15. Bektas, I.; Guler, C.; Kalaycioğlu, H.; Mengeloglu, F.; Nacar, M. The Manufacture of Particleboards using Sunflower Stalks (Helianthus annuus L.) And Poplar Wood (Populus alba L.). J. Compos. Mater. 2005, 39, 467-473. [CrossRef]

16. Klímek, P.; Meinlschmidt, P.; Wimmer, R.; Plinke, B.; Schirp, A. Using sunflower (Helianthus annuus L.), topinambour (Helianthus tuberosus L.) and cup-plant (Silphium perfoliatum L.) stalks as alternative raw materials for particleboards. Ind. Crop. Prod. 2016, 92, 157-164. [CrossRef]

17. Klímek, P.; Wimmer, R.; Mishra, P.; Kúdela, J. Utilizing brewer's-spent-grain in wood-based particleboard manufacturing. J. Clean. Prod. 2017, 141, 812-817. [CrossRef]

18. Wang, X.; Fang, H.; Feng, M.; Zhang, Y.; Yan, N. Manufacturing Medium-Density Particleboards from Wood-Bark Mixture and Different Adhesive Systems. For. Prod. J. 2015, 65, 20-25. [CrossRef]

19. Lakreb, N.; As, N.; Gorgun, V.; Sen, U.; Gomes, G.; Pereira, H. Production and characterization of particleboards from cork-rich Quercus cerris bark. Eur. J. Wood Prod. 2018, 76, 989-997. [CrossRef]

20. Medved, S.; Tudor, E.M.; Barbu, M.C.; Jambreković, V.; Španić, N. Effect of Pine (Pinus Sylvestris) Bark Dust on Particleboard Thickness Swelling and Internal Bond. Drv. Ind. 2019, 70, 141-147. [CrossRef]

21. Merkel, K.; Rydarowski, H.; Kazimierczak, J.; Bloda, A. Processing and characterization of reinforced polyethylene composites made with lignocellulosic fibres isolated from waste plant biomass such as hemp. Compos. B Eng. 2014, 67, 138-144. [CrossRef]

22. Yu, X.; Xu, H. Lightweight Composites Reinforced by Agricultural Byproducts. In Lightweight Materials from Biopolymers and Biofibers; American Chemical Society: Omaha, NE, USA, 2014; pp. 209-238. 
23. Bowyer, J.; Stockmann, V. Agricultural residues: An exciting bio-based raw material for the global panels industry. Forest Prod. J. 2001, 51, 10-21.

24. Siti Suhaily, S.; Khalil, A.; Asniza, M.; Nurul Fazita, M.; Mohamed, A.; Dungani, R.; Zulqarnain, W.; Syakir, M. Design of green laminated composites from agricultural biomass. In Lignocellulosic Fibre and Biomass-Based Composite Materials; Elsevier: Sawston, UK, 2017; pp. 291-311.

25. Papadopoulou, E.; Chrissafis, C. Particleboards from agricultural lignocellulosics and biodegradable polymers prepared with raw materials from natural resources. In Natural Fiber-Reinforced Biodegradable and Bioresorbable Polymer Composites; Woodhead Publishing: Sawston, UK, 2017; pp. 19-30.

26. Figen-Antmen, Z. Exploitation of Peanut and Hazelnut Shells as Agricultural Industrial Wastes for Solid Biofuel Production. Fresenius Environ. Bull. 2019, 28, 2340-2347.

27. Flores-Johnson, E.; Carrillo, J.; Zhai, C.; Gamboa, R.; Gan, Y.S.L. Microstructure and mechanical properties of hard Acrocomia mexicana fruit shell. Sci. Rep. 2018, 8, 9668. [CrossRef] [PubMed]

28. Statista. Production of Tree Nuts Worldwide in 2019/2020, by Type (in 1,000 Metric Tons). Available online: https://www.statista.com/statistics/1030790/tree-nut-global-production-by-type/ (accessed on 19 August 2020).

29. Martínez, M.; Moiraghi, L.; Agnese, M.; Guzman, C. Making and some properties of activated carbon produced from agricultural industrial residues from Argentina. J. Argent. Chem. Soc. 2003, 91, 104-108. [CrossRef]

30. Gürü, M.; Aruntaş, Y.; Tüzün, F.; Bilici, I. Processing of urea-formaldehyde-based particleboard from hazelnut shell and improvement of its fire and water resistance. Fire Mater. 2009, 33, 413-419. [CrossRef]

31. Güler, C.; Çöpür, Y.; Büyüksari, U. Producing particleboards from hazelnut (Corylus avellana L.) husk and European Black Pine (Pinus nigra Arnold). Wood Res. 2009, 54, 125-132.

32. Kowaluk, G.; Kądziela, J. Properties of particleboard produced with use of hazelnut shells. Ann. WULS SGGW Wood Technol. 2014, 85, 131-134.

33. Gürü, M.; Atar, M.; Yıldırım, R. Production of polymer matrix composite particleboard from walnut shell and improvement of its requirements. Mater. Des. 2008, 29, 284-287. [CrossRef]

34. Pirayesh, H.; Khanjanzadeh, H.; Salarib, H. Effect of using walnut/almond shells on the physical, mechanical properties and formaldehyde emission of particleboard. Compos. Part. B Eng. 2013, 45, 858-863. [CrossRef]

35. Güler, C.; Cöpur, Y.; Tascioglu, C. The manufacture of particleboards using mixture of peanut hull (Arachis hypoqaea L.) and European Black pine (Pinus nigra Arnold) wood chips. Bioresour. Technol. 2008, 99, 2893-2897. [CrossRef]

36. Batalla, L.; Nuñez, A.; Marcovich, N. Particleboards from peanut-shell flour. J. Appl. Polym. Sci. 2005, 97, 916-923. [CrossRef]

37. Gürü, M.; Tekeli, S.; Bilici, I. Manufacturing of urea-formaldehyde-based composite particleboard from almond shell. Mater. Des. 2006, 27, 1148-1151. [CrossRef]

38. Pirayesh, H.; Khazaeian, A. Using almond (Prunus amygdalus L.) shell as a bio-waste resource in wood-based composite. Compos. Part. B Eng. 2012, 43, 1475-1479. [CrossRef]

39. Chaudhary, A.; Gope, P.; Singh, V. Effect of Almond Shell Particles on Tensile Property of Particleboard. J. Mater. Environ. Sci. 2013, 4, 109-112.

40. EN 326:2012. Wood-Based Panels—Sampling, Cutting and Inspection-Part 1: Sampling and Cutting of Test Pieces and Expression of Test Results; European Committee for Standardization: Brussels, Belgium, 2012.

41. EN 310:2005. Wood-Based Panels: Determination of Modulus of Elasticity in Bending and of Bending Strength; European Committee for Standardization: Brussels, Belgium, 2005.

42. EN 1534:2010. Wood flooring-Determination of Resistance to Indentation-Brussels, Belgium; European Committee for Standardization: Brussels, Belgium, 2010.

43. EN 317:2005. Particleboards and fibreboards-Determination of Swelling in Thickness after Immersion in Water; European Committee for Standardization: Brussels, Belgium, 2005.

44. EN 323:2015. Wood-based Panels_Determination of Density; European Committee for Standardization: Brussels, Belgium, 2015.

45. EN 120:2011. Wood-Based Panels-Determination of Formaldehyde Release-Extraction Method (Called Perforator Method); European Committe for Standardization: Brussels, Belgium, 2011.

46. Pirayesh, H.; Khazaeian, A.; Tabarsa, T. The potential for using walnut (Juglans regia L.) shell as a raw material for wood-based particleboard manufacturing. Compos. Part. B Eng. 2012, 43, 3276-3280. [CrossRef] 
47. Pizzi, A.; Mittal, K. Handbook of Adhesive Technology; Dekker: New York, MY, USA, 1994.

48. Dunky, M.; Niemz, P. Holzwerkstoffe und Leime: Technologie und Einflussfaktoren, Mit 150 Tabellen; Springer: Berlin, Germany, 2002.

49. Tabarsa, T.; Ashori, A.; Gholamzadeh, M. Evaluation of surface roughness and mechanical properties of particleboard panels made from bagasse. Comp. Part. B Eng. 2011, 42, 1330-1335. [CrossRef]

50. Kollmann, F. Technologie des Holzes und der Holzwerkstoffe, 2nd ed.; Springer: Berlin, Germany, 1982.

51. Zeppenfeld, G.; Grunwald, D. Klebstoffe in der Holz- und Möbelindustrie, 2nd ed.; Weinbrenner, DRW-Verlag: Leinfelden-Echterdingen, Germany, 2005.

52. Gwon, J.; Lee, S.; Chun, S.; Doh, G.; Kim, J. Effects of chemical treatments of hybrid fillers on the physical and thermal properties of wood plastic composites. Compos. Part. A Appl. Sci. Manuf. 2010, 41, 1491-1497. [CrossRef]

53. Tudor, E.M.; Barbu, M.C.; Petutschnigg, A.; Réh, R.; Krišt'ák, L'. Analysis of Larch-Bark Capacity for Formaldehyde Removal in Wood Adhesives. Int. J. Environ. Res. Public Health 2020, 17, 764. [CrossRef]

54. Roffael, E.; Johnsson, B.; Engström, B. On the measurement of formaldehyde release from low-emission wood-based panels using the perforator method. Wood Sci. Technol. 2010, 44, 369-377. [CrossRef]

55. Medved, S.; Gajšek, U.; Tudor, E.M.; Barbu, M.C.; Antonović, A. Efficiency of bark for reduction of formaldehyde emission from particleboards. Wood Res. 2019, 64, 307-316.

56. Réh, R.; Igaz, R.; Krišt'ák, L'.; Ružiak, I.; Gajtanska, M.; Božíková, M.; Kučerka, M. Functionality of Beech Bark in Adhesive Mixtures Used in Plywood and Its Effect on the Stability Associated with Material Systems. Materials 2019, 12, 1298. [CrossRef] [PubMed]

57. Şenol, H. Biogas potential of hazelnut shells and hazelnut wastes in Giresun City. Biotechnol. Rep. 2019, 24, e00361. [CrossRef] [PubMed]

58. Nicolao, E.S.; Leiva, P.; Chalapud, M.C.; Ruseckaite, R.A.; Ciannamea, E.M.; Stefani, P.M. Flexural and tensile properties of biobased rice husk-jute-soybean protein particleboards. J. Build. Eng. 2020, 30, 101261. [CrossRef]

59. EN 312:2005. Particleboards_Specifications_Part 3: Requirements for Boards for Use in Interior Fitments (Including Furniture) in Dry Conditions; European Committee for Standardization: Brussels, Belgium, 2005.

(C) 2020 by the authors. Licensee MDPI, Basel, Switzerland. This article is an open access article distributed under the terms and conditions of the Creative Commons Attribution (CC BY) license (http://creativecommons.org/licenses/by/4.0/). 